\title{
A Novel Mechanism for Delivering IPTV Traffic in Ethernet Passive Optical Networks
}

\section{Mekanisme Baru untuk mengirimkan IPTV Traffic di Ethernet Passive Optical Network}

\author{
Andrew Tanny Liem ${ }^{1}$ \\ ${ }^{1}$ Teknik Informatika, Fakultas Ilmu Komputer \\ Universitas Klabat, 95371 \\ andrew.heriyana@unklab.ac.id
}

\begin{abstract}
Abstrak
IPTV menawarkan layanan televisi digital melalui Internet Protocol (IP) untuk pelanggan dengan biaya murah. Meskipun semua layanan IPTV sangat menarik, namun hal itu juga memerlukan akses jaringan berkecepatan tinggi dengan fungsi multicasting, Quality-of-Services (QoS) dan sebagainya. Dalam access network, Ethernet Passive Optical Network (EPON) dianggap sebagai salah satu teknologi terbaik untuk memenuhi kebutuhan bandwidth yang besar, seperti aplikasi IPTV. Ada dua mekanisme yang umum digunakan untuk menyalurkan IPTV kepada pengguna dalam sistem EPON yaitu, dedicated stream dan multicast stream. Dedicated stream tidak scalable bilamana jumlah pelanggan sangat banyak, karena keterbatasan bandwidth dan konsumsi sumber daya di sisi server. Sebaliknya, meskipun multicast dapat digunakan sebagai solusi scalable untuk media streaming, tetapi menyediakan layanan tersebut di EPON masih sulit karena beberapa keterbatasan dalam sistem EPON. Dalam paper ini, kami merancang mekanisme baru dengan menggunakan Single Copy Broadcast (SCB) dengan Priority Queue (PQ) yang dapat menampung jumlah pelanggan IPTV yang banyak tanpa perlu menambahkan bandwidth dan sumber daya tambahan pada Optical Line Terminal (OLT). Hasil simulasi menunjukkan bahwa mekanisme yang rancang dapat meningkatkan QoS metrik dan sistem kinerja dalam hal konsumsi bandwidth dan konsumsi daya.
\end{abstract}

Kata kunci - IPTV, QoS, EPON, Unicast, Multicast, Single Copy Broadcast.

\begin{abstract}
IPTV offers digital television services over Internet Protocol (IP) for the subscribers at a lower cost. Despite all the attractive IPTV services, it also requires high-speed access networks with the functions of multicasting, Quality-of-Services (QoS) guarantee and so on. In the access networks, Ethernet Passive Optical Network (EPON) is regarded as one of the best technology to meet the higher bandwidth demands applications such as IPTV. There are two common mechanisms used for delivering IPTV to the users in the EPON system such as, dedicated stream and multicast stream. The dedicated stream is not scalable to a large number of clients because of the limited bandwidth and resource consumption at the server side. Conversely, although multicast could be used as a scalable solution for media streaming, but providing such services in the EPON is still challenging due to some limitations in the EPON system. In this paper, we propose a new mechanism that is a Single Copy Broadcast (SCB) with Priority Queue (PQ) mechanism that can accommodate large number of clients IPTV streams without adding extra bandwidth and resources at the Optical Line Terminal (OLT). Simulation results have shown that our proposed mechanism can improve the QoS metrics and system performance in terms of bandwidth consumption and power consumption.
\end{abstract}

Keywords - IPTV, QoS, EPON, Unicast, Multicast, Single Copy Broadcast.

\section{INTRODUCTION}

Newly evolving multimedia applications such as high-definition television (HDTV), Internet Protocol Television (IPTV), and Video-on-Demand (VoD) in recent times become one of the most key services for network operators. It is predicted that 1.2 million minutes of video content will cross the network every second in 2016 and the sum of all forms of video traffic 
(TV, VoD, Internet, and P2P) will be approximately 86 percent of global consumer traffic by 2016 [1]. These applications have brought the network operators to offer higher bandwidth to their residential and business subscribers. Among these applications, IPTV is one of the killer multimedia applications for the next-generation network, yet provides exciting new revenue and opportunities for service providers. IPTV offers digital television services over Internet Protocol (IP) for the subscribers at a lower cost. These IPTV services can include live television, timeshifted television, and video on demand (VoD) [2]. Despite all the attractive IPTV services, it also requires high-speed access networks with the functions of multicasting, Quality-of-Services (QoS) guarantee and so on.

In the access network, EPON is considered as one of the best solution to meet applications with higher demands of bandwidth such as, IPTV and VoD. The EPON architecture consists of a centralized optical line terminal (OLT), a number of splitters and optical network units (ONUs) as shown in Figure 1. The OLT connects to multiples associated ONUs over point-to-multipoint topologies to deliver broadband packets and reduce costs relative to the maintenance power. In addition, the OLT has the entire channel bandwidth to broadcast the control messages and data packets to each ONU since the directional properties of the splitter or coupler is used. Because EPON is broadcasting by nature in the downstream direction, therefore the OLT will broadcast the control messages and data packets and selectively extracted by their destination ONU. In addition, the SCB is introduced so that the OLT can forward the broadcast packets to multiple recipients without multiple duplications for each ONU [3]. However, in the upstream direction, the entire ONUs must share the common transmission channel towards the OLT, and only a single ONU may upload upstream data in its transmission timeslot to avoid data collisions. Therefore, the IEEE 802.3ah standard has developed a Multipoint Control Protocol (MPCP), thus each ONU transmits within a dedicated timeslot and the OLT receives a continuous stream of collision-free packets from each ONU.

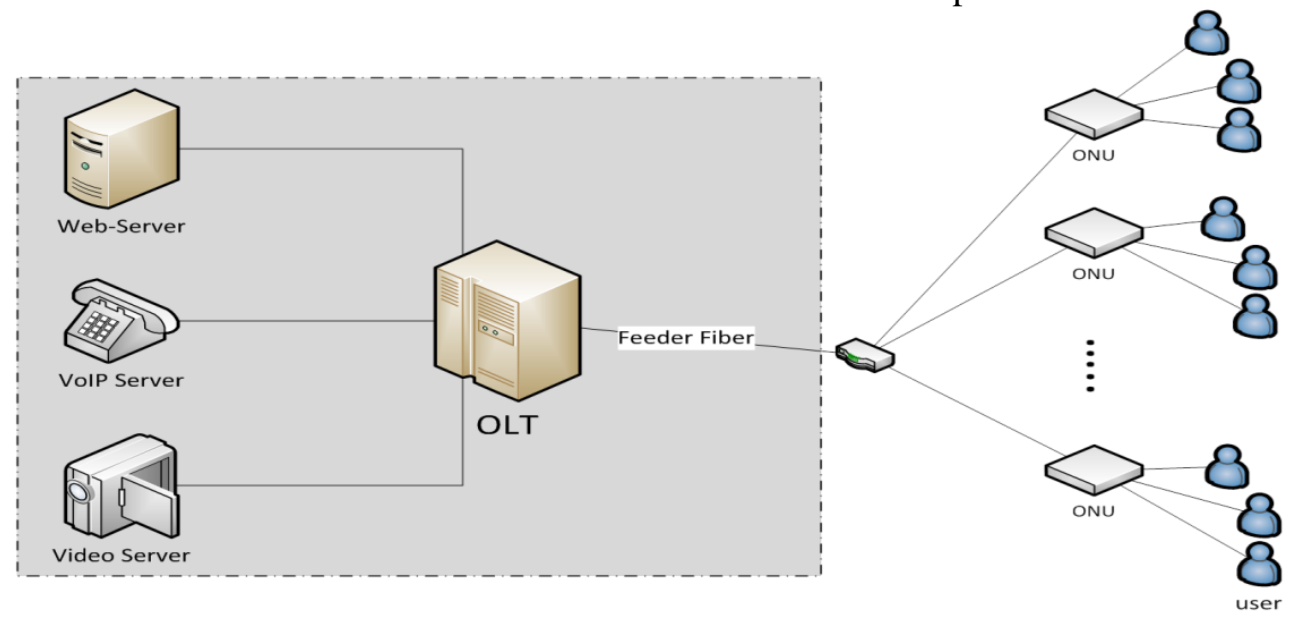

Figure 1. EPONs Architecture

As mentioned above, there are two techniques to deliver the video from server to the users, which are unicast and multicast. Unicast is define as one-to one connection between the client and the server, thus when a client connects using unicast to a Video server, that client has a direct relationship to the server. Each unicast client that connects to the server takes up additional bandwidth. For example, if you have 10 clients all playing 100-kilobits per second (Kbps) streams, those clients as a group are taking up 1,000 Kbps. If you have only one client playing the $100 \mathrm{Kbps}$ stream, only $100 \mathrm{Kbps}$ is being used. On the other hand, multicast defines as delivery of Video data from Video Server to a group of clients simultaneously, thus each client that connects to the multicast adds no additional overhead/bandwidth on the server. In fact, the server sends out only one stream per multicast group (the same load is experienced on 
the server whether only one client or 1,000 clients are connecting in the same multicast group). Therefore, for the IPTV services the unicast is very inefficient regardless of payload consumption.

Consequently, to tackle the aforementioned problems and challenges, in this paper, we propose a new technique that can accommodate large number of clients without adding extra bandwidth and resources both at the OLT. We emulate the Single Copy Broadcast (SCB) mechanism with separate queue or Priority Queue (PQ) over EPON system for efficiently distribute the video traffic, particularly for delivering live IPTV traffics.

\section{RESEARCH METHOD}

The research method conducted in this paper is illustrated in Figure 2. The first two steps are explain in the following sub sections, whereas the last step will be explained in section 3.
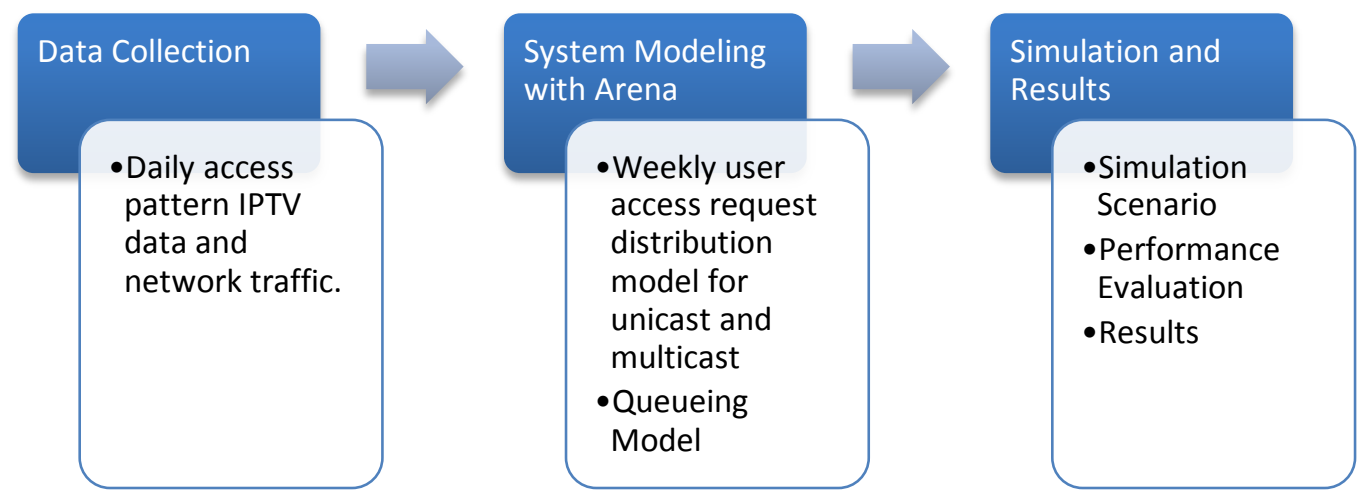

Figure 2. Research Method

\subsection{Data Collection}

When the service provider provides IPTV service, each channel has different popularity, and the popularity of a channel correlates with the request rate for the channel. The popularity of a channel may decrease with time, since user interest for a channel decreases after some time. The popularity of a channel may also change due to external factors such as introduction of new shows, special events (e.g., Olympic Games, big match game, etc) and recommendation of channels [4]. Users may have different preferences for each channel and have diverse preferable time to watch an IPTV. However, the overall request patterns from all clients follow a uniform curve and constitute daily and weekly access patterns, which are very important parameters for the service provider to consider for their network design.

A key parameter to show the access pattern of a video is the popularity of the movie with the Zipf distribution. Probability Density Function (PDF) of Zipf distribution is given as $p(i)=C / i^{\alpha}$, where $C=1 / \sum_{j=1}^{N} 1 / j^{\alpha}, \mathrm{N}$ is total number movies in the system, $\mathrm{i}$ is the rank of video in decreasing popularity order, $\alpha$ is the skew factor between 0.65 and 1 with mean value of 0.801 and $p(i)$ is the popularity of movie $i$. The popularity of a video will be decreased over time, but for a long period of time over weeks, user interest for most popular (top 10 to 20) is very high when compared to the top 100 or top 200 videos. Because of the skewed movie popularity distribution, most of the user requests are accounted for by a few movies. For example, $10 \%$ of the most popular movies accounts for approximately $60 \%$ of all accesses.

Most popular channel listings provided by the service provider may also affect the popularity of a channel. Figure 3 shows an example on how a most popular list affects the 
access frequency of a channel; a channel is accessed more frequently while it is on top-15 hot list, but its rank and access frequency drops significantly and cannot recover the popularity once it is out of the top-15 hot list, as shown in the Figure 3.

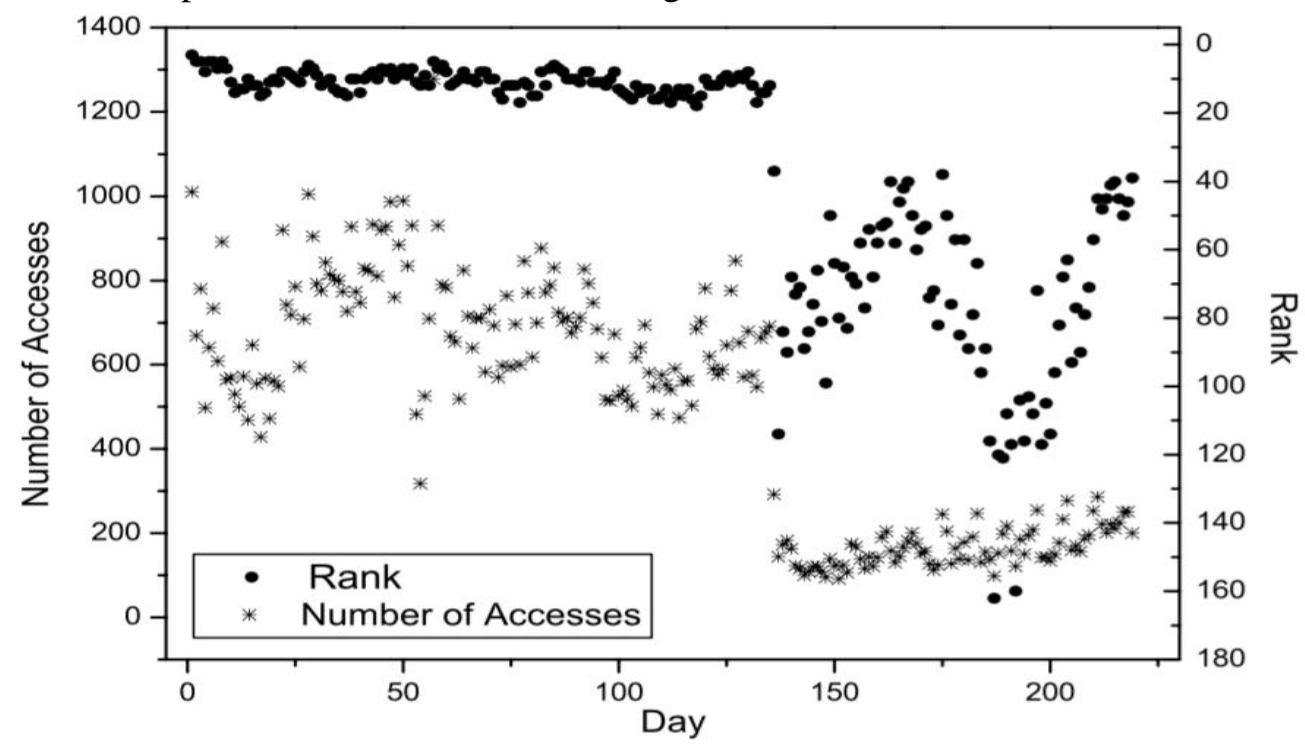

Figure 3. Number of Accesses IPTV over months [4]

Daily access pattern, which is related to user behavior, is another important factor in IPTV service. As shown in Figure 4, IPTV request pattern for channels during a day has similar pattern and almost the same for a week: it climbs up to a peak after work (8 pm - $10 \mathrm{pm})$, and gradually decreases. This same pattern will be repeated over a week and has the highest rate on week-end (i.e., Saturday, Sunday). This request pattern may change a little bit based on the working hours in different countries, but they all show the same information that users enjoy IPTV service during afternoon break and after work. An interesting point to note is that the request rate for channels is quite low during most of the day except between $6 \mathrm{pm}$ - midnight, and is highly time-predictable.

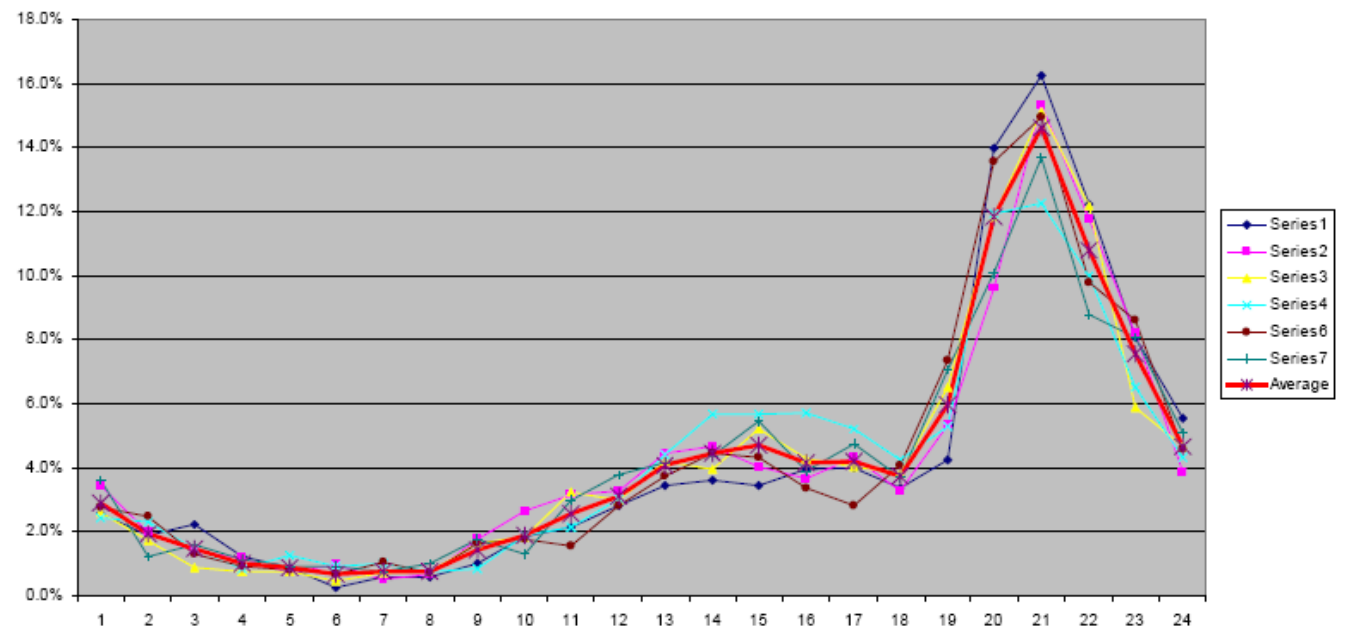

Figure 4. IPTV Request Change in 24 Hours [4]

In our paper, we focus only at the peak time which starts from 8 p.m to 10 p.m. Therefore, based on the aforementioned facts, the user request can be defined as follows:

user_request $=$ user_request_change $(\%)$ *number_of_accesses 


\subsubsection{Request Access Pattern and IPTV Traffic Data Collection}

To collect the unicast user request access pattern of IPTV, we used small program to calculate the average user request access pattern in 7 days. Table I shows the results of the data that were collected. Moreover, the multicast user request access pattern can be calculated as:

Multicast_request_access_pattern $=$ unicast_request_access_pattern *max_no_of_user_per_group,

Where, max_no_of_user_per_group is approximately $10 \%$ from unicast_request_access_pattern according to the literatures. Table II shows the results of multicast request access pattern in 7 days based on the unicast request access pattern data that already been collected.

Table I. Unicast Request Access Pattern

\begin{tabular}{|c|c|}
\hline Days & $\begin{array}{l}\text { Average User } \\
\text { Request/day }\end{array}$ \\
\hline 1. & 182 \\
\hline 2. & 201.5 \\
\hline 3. & 208 \\
\hline 4. & 201.5 \\
\hline 5. & 195 \\
\hline 6. & 188.5 \\
\hline 7. & 182 \\
\hline
\end{tabular}

Table II. Multicast Request Access Pattern

\begin{tabular}{|c|c|}
\hline Days & $\begin{array}{l}\text { Average User } \\
\text { Request/day }\end{array}$ \\
\hline 1. & 18.2 \\
\hline 2. & 18.85 \\
\hline 3. & 19.5 \\
\hline 4. & 20.15 \\
\hline 5. & 20.8 \\
\hline 6. & 20.15 \\
\hline 7. & 19.5 \\
\hline
\end{tabular}

In order to fit it into a distribution, we used input analyzer from Arena Software based on the raw data that have been collected from our experiments to FIT our collected data for unicast user request and multicast user request to some distributions. We found that the unicast user request pattern is FIT to the $\operatorname{NORM}(194,8.55)$ distributions, whereas the multicast user request pattern is FIT to the $18+3 * \operatorname{BETA}(1.02,1.23)$ distributions. Moreover, Table III and IV summarize the input analyzer results, respectively.

Table III. Unicast User Request Input Analyzer Results

\begin{tabular}{|c|l|l|}
\hline No. & \multicolumn{1}{|c|}{ Parameters } & \multicolumn{1}{c|}{ Value } \\
\hline 1. & Number of Data Points & 7 \\
\hline 2. & Min Data Value & 182 \\
\hline 3. & Max Data Value & 208 \\
\hline 5. & Sample Mean & 196 \\
\hline 6. & Sample Std Dev & 8.74 \\
\hline 7. & p-value & $>0.15$ \\
\hline 8. & Test Statistics & 0.149 \\
\hline 9. & Square Error & 0.010052 \\
\hline
\end{tabular}


Table IV. Multicast user Request Input Analyzer Results

\begin{tabular}{|c|l|l|}
\hline No. & \multicolumn{1}{|c|}{ Parameters } & \multicolumn{1}{c|}{ Value } \\
\hline 1. & Number of Data Points & 7 \\
\hline 2. & Min Data Value & 18.2 \\
\hline 3. & Max Data Value & 20.8 \\
\hline 5. & Sample Mean & 19.4 \\
\hline 6. & Sample Std Dev & 0.906 \\
\hline 7. & p-value & $>0.15$ \\
\hline 8. & Test Statistics & 0.113 \\
\hline 9. & Square Error & 0.002283 \\
\hline
\end{tabular}

IPTV data was taken from real data collection from [5], which is followed the tri-modal distribution as shown in Figure 5. To be noted that we are also using input analyzer in Arena to fit the IPTV traffic class. Although we could not fit to any distribution, we use the discrete function to model the tri-modal distribution.

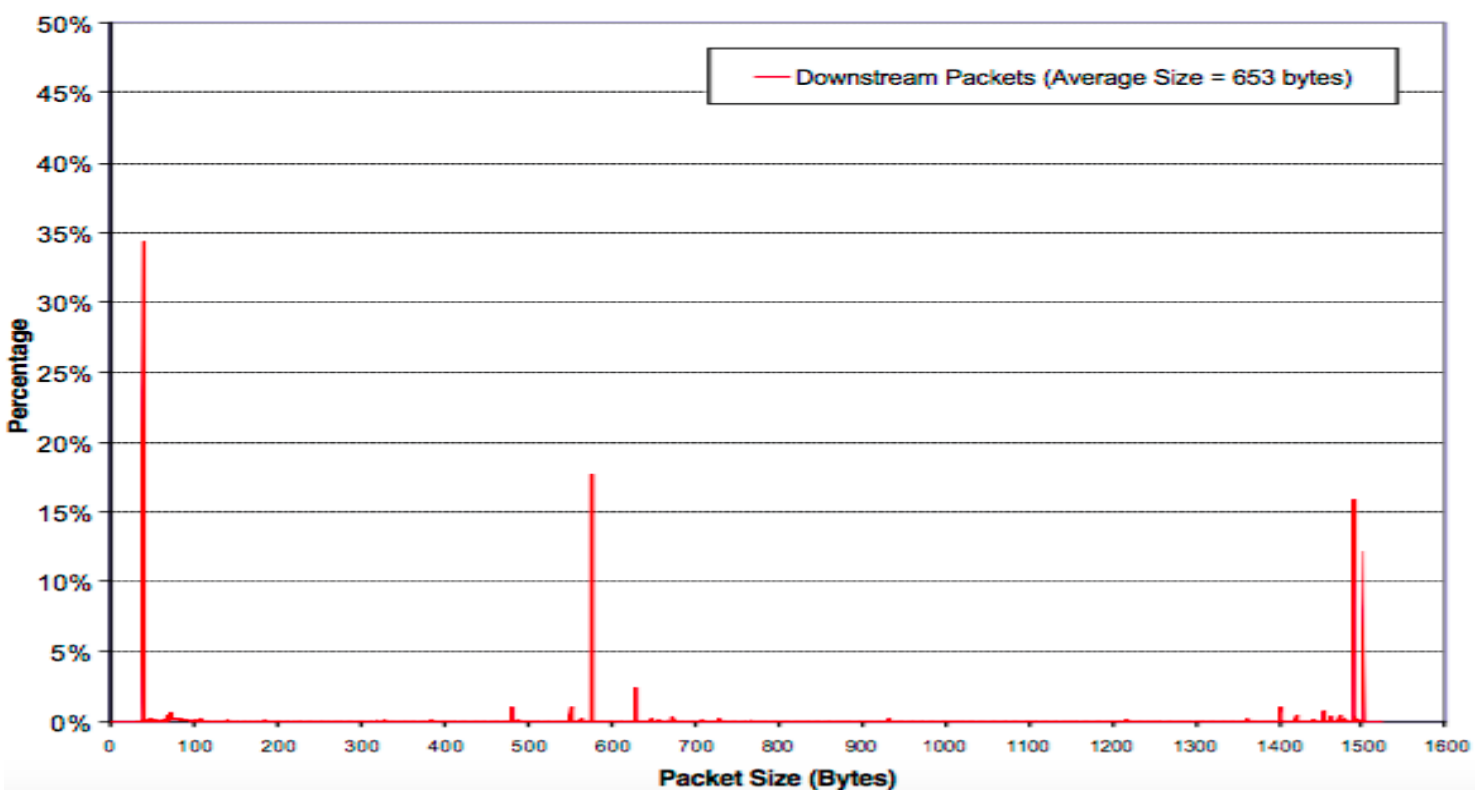

Figure 5. IPTV Packet Size Distribution [5]

\subsection{System Modeling with Arena Software}

To model the network traffic an extensive study has shown that most network traffic can be characterized by self-similarity and long-range dependence (LRD) [1]. This model is utilized to generate highly busty Web-server and IPTV traffic classes with the Hurst parameter of 0.7 , and the packet sizes of Web-server class is uniformly distributed between 64 and 1518 bytes [2-8], whereas IPTV traffic class is followed the tri-modal distribution as shown in Figure 5 [5]. On the other hand, high-priority traffic (e.g., voice applications) is modeled using a uniform distribution and packet size is uniform between 65 to 75 bytes [2-8].

The interarrival time of each traffic class is calculated based on the following formula:

EF inter-arrival time

EF_interval $=E F \_$size $/($EF_proportion $*$ rate $)$

BE inter-arrival time

BE_interval $=\mathrm{BE} \_$size $/\left(\mathrm{BE} \_\right.$proportion $*$ rate $)$.

AF inter-arrival time 
AF_interval $=$ AF_size / (channel_rate $*$ channel_number)

where, rate is the feeder fiber bandwidth (i.e., $100 \mathrm{Mbps}$ ), channel rate is equal to 30 Mbps/channel and channel number is between 10 to 40 channels.

\subsubsection{Queuing System Model}

First-In-First-Out (FIFO) is the queuing system use in the current downstream direction of EPON system. FIFO is the most basic queue scheduling discipline. In FIFO queuing, all the traffics are treated equally by placing them into a single queue, and servicing them in the same order were the traffics placed into the queue as shown in Figure 6(a). Some others references also referred FIFO as First-Come, First-Serve (FCFS) queuing. Figure 6(b) shows the current FIFO queuing system in the OLT when the buffer is full. It is shown that when the arriving packet found that no space left in the buffer, the OLT soon start to drop the packet until there is an empty buffer that sufficient to the arriving packets. Notice that the most common buffer size at the OLT is 10 Mbytes.

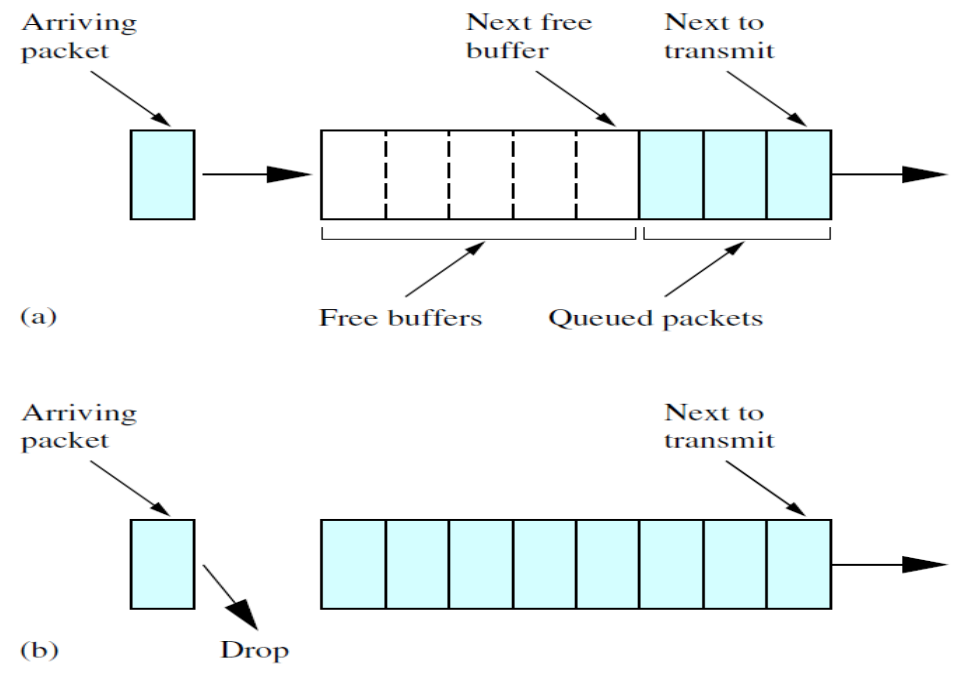

Figure 6(a) FIFO Queuing System; (b) FIFO Drop Packet

To improve the Quality-of-Services (QoS) of the current system (i.e., FIFO), we propose two queuing system model referred as "Separate Buffer" and "Separate Buffer Priority Queue (PQ)". The objective of the proposed queuing system is that we servicing the packets differently and placing them into different buffer. In the separate buffer, we simply separate and place the arriving packets into different buffer. We divide the buffer into three (i.e., P1 for Highest Priority packet (Voice), P2 for higher priority packet (IPTV) and P3 for lowest priority (Data)), each buffer has approximately 3 Mbytes. Therefore, when the packet is arriving, first the OLT will check the packet, distinguish the packet and place it in the correct buffer priority based on the packet priority. On the other hand, the "separate buffer PQ" working principles are similar to the "separate buffer", but have different rule for dropping the packet in case of buffer overflow. When the highest priority buffer is full, the OLT will allocate the highest priority packet (i.e., Voice) to the lowest priority buffer. And if the lowest priority buffer is also full, then the OLT will begin to drop the lowest priority traffic until satisfy the highest priority traffic. However, when the entire lower priority buffer is full with highest priority packet, then OLT will begin to drop the highest priority packet. Figure 7 and 8 show the proposed queuing model. 

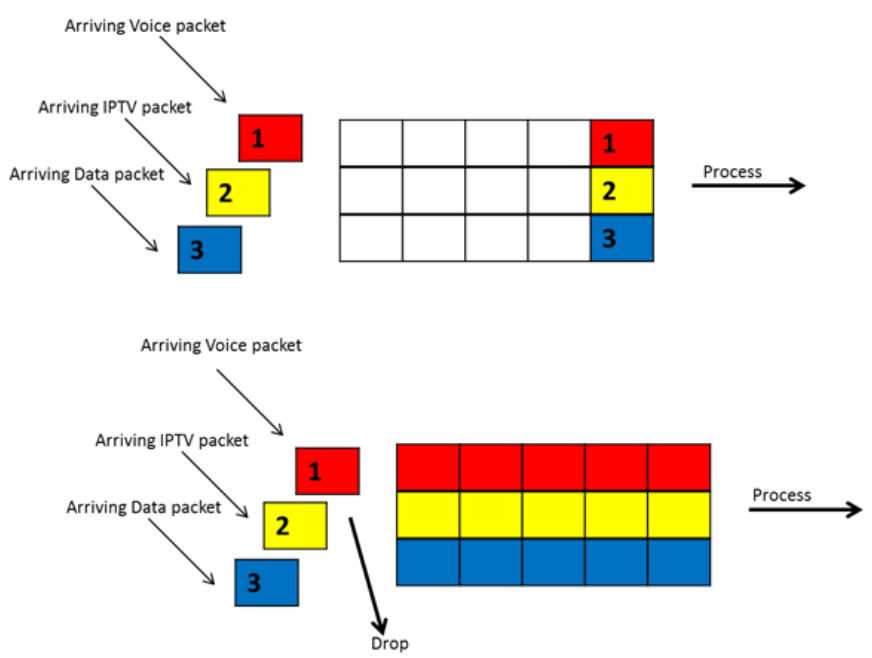

Figure 7. Proposed Separate Buffer Queuing System Model
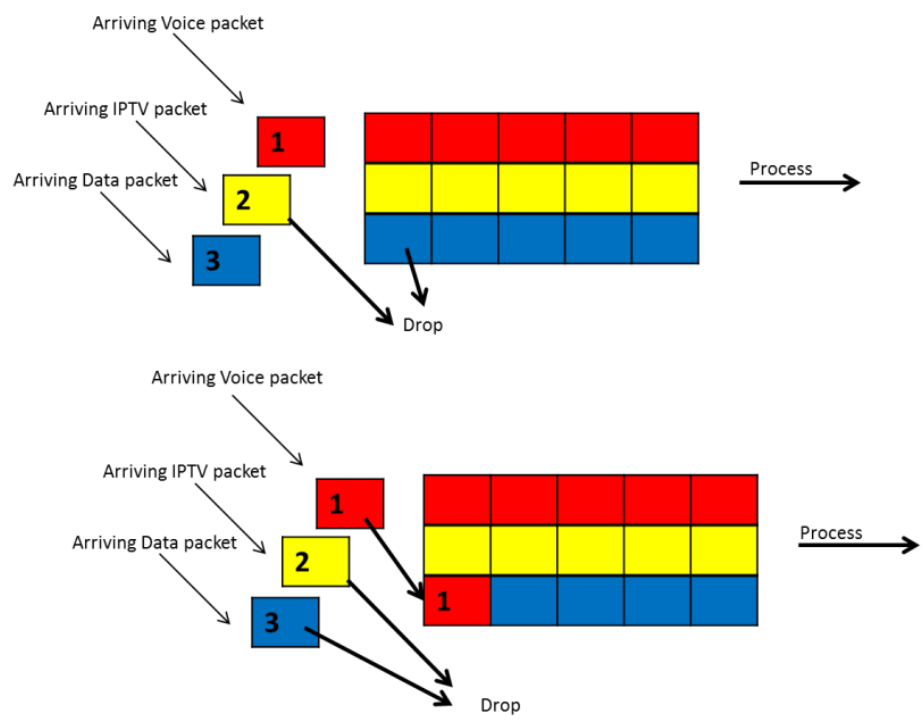

Figure 8. Proposed Separate Buffer Priority Queuing (PQ) Queuing System Model

\section{PERFORMANCE EVALUATION AND RESULTS}

In this section, the performance of the proposed mechanism is evaluated using Arena Software. Table V and VI summarize the parameters distribution and other parameters used in Arena Software, respectively. Moreover, to evaluate the improvement of our proposed architecture and the effect of increasing IPTV channel, the performance is analyzed by simulating three different scenarios with three distinctive queuing systems, which are: 1) (a) share_unicast; (b) separate_unicast; (b)PQ_unicast; 2) (a) share_multicast; (b) separate_multicast; (c) PQ_multicast; 3) (a) share_SCB; (b) separate_SCB; (c) PQ_SCB. The channel is set up from 10 to 40 channels with bitrate $30 \mathrm{Mbps} / \mathrm{channel}$. However, due to the page limitation, only share_unicast, PQ_unicast, PQ_multicast and PQ_SCB will be shown and discussed. 
Table V. Parameters Distributions

\begin{tabular}{|l|l|c|l|}
\hline No. & \multicolumn{1}{|c|}{ Parameters } & Distribution & \multicolumn{1}{|c|}{ Description } \\
\hline 1. & Unicast_user_behavior_request & $\operatorname{NORM}(194,8.55)$ & $\begin{array}{l}\text { The user behavior request of } \\
\text { current unicast video delivery in } \\
\text { EPON }\end{array}$ \\
\hline 2. & Multicast_user_behavior_request & $18+3 *$ BETA(1.02, \\
$1.23)$ & $\begin{array}{l}\text { The user behavior request of } \\
\text { multicast video delivery in } \\
\text { EPON }\end{array}$ \\
\hline 3. & Voice (EF) Packet Size & $\mathrm{UNIF}(65,75)$ & The packet size of voice \\
\hline 4. & IPTV (AF) Packet Size & $\begin{array}{l}\text { DISC }(0.0003,34,0.3441, \\
40,0.3444,41,0.3450, \ldots \\
\ldots)\end{array}$ & $\begin{array}{l}\text { The packet size of IPTV } \\
\text { Details in [8] }\end{array}$ \\
\hline 5. & Data (BE) Packet Size & $\mathrm{UNIF}(64,1518)$ & The packet size of Data \\
\hline
\end{tabular}

Table VI. Other Parameters

\begin{tabular}{|c|c|c|c|}
\hline No. & Parameters & Values & Description \\
\hline 1. & Shared Buffer Size & 10 Mbytes (10000000 bit) & $\begin{array}{l}\text { The capacity of shared buffer } \\
\text { size in The OLT }\end{array}$ \\
\hline 2. & $\begin{array}{l}\text { Proposed Separate Buffer } \\
\text { Size }\end{array}$ & 3 Mbytes & 3 Mbytes are for each buffer \\
\hline 3. & $\begin{array}{l}\text { Proposed Separate Buffer } \\
\text { Size PQ }\end{array}$ & 3 Mbytes & 3 Mbytes are for each buffer \\
\hline 4. & $\begin{array}{l}\text { Resource Capacity of the } \\
\text { OLT }\end{array}$ & 10 Mbytes (10000000 bit) & $\begin{array}{l}\text { The Resource capacity of the } \\
\text { OLT in the EPON system }\end{array}$ \\
\hline 5. & Processing Time of the OLT & $\mathrm{UNIF}(0.0009,0001)$ & $\begin{array}{l}\text { The processing time of the } \\
\text { OLT to process the packets }\end{array}$ \\
\hline 6. & rate/Feeder Fiber Capacity & 100 Mbytes (125000000 bits) & $\begin{array}{l}\text { The bandwidth capacity in } \\
\text { the feeder fiber }\end{array}$ \\
\hline 7. & Channel Rate & $30 \mathrm{Mbps} /$ channel & The bitrate of each channel \\
\hline 8. & $\begin{array}{l}\text { Total Number of IPTV } \\
\text { Channel }\end{array}$ & 40 Channel & IPTV Channel in the system \\
\hline 9. & $\begin{array}{l}\text { Delay Time for Transmitting } \\
\text { the packet }\end{array}$ & $\mathrm{UNIF}(0.003,0.005)$ & $\begin{array}{l}\text { The delay time for } \\
\text { transmitting the packet in the } \\
\text { feeder fiber }\end{array}$ \\
\hline 10. & $\begin{array}{l}\text { Voice (EF) Traffic } \\
\text { Proportion }\end{array}$ & $20 \%$ & $\begin{array}{l}\text { The Traffic Proportion in the } \\
\text { System for Voice }\end{array}$ \\
\hline 11. & Data (BE) Traffic Proportion & $20 \%$ & $\begin{array}{l}\text { The Traffic Proportion in the } \\
\text { System for Voice }\end{array}$ \\
\hline 12. & Voice (EF) inter-arrival time & $\begin{array}{l}\mathrm{EF}_{\text {interval }} \\
=\frac{\text { EF_packet_size }}{\text { EF_proportion } \times \text { rate }}\end{array}$ & $\begin{array}{l}\text { The inter-arrival time for } \\
\text { Voice }\end{array}$ \\
\hline 13. & Data $(\mathrm{BE})$ inter-arrival time & $\begin{array}{l}\text { BE } \begin{array}{l}\text { interval } \\
=\frac{\text { BE_packet_size }}{\text { BE_proportion } \times \text { rate }}\end{array}\end{array}$ & $\begin{array}{l}\text { The inter-arrival time for } \\
\text { Data }\end{array}$ \\
\hline 14. & IPTV (AF) inter-arrival time & $\begin{array}{l}\mathrm{AF}_{\text {interval }} \\
=\frac{\mathrm{AF} \text { _packet_size }}{\mathrm{AF} \_ \text {proportion } \times \text { rate }}\end{array}$ & $\begin{array}{l}\text { The inter-arrival time for } \\
\text { IPTV }\end{array}$ \\
\hline
\end{tabular}

Figure 9 to 10 show the system performance of bandwidth consumption and power consumption for unicast and multicast compared with our proposed mechanism (i.e., SCB). It can be observed the proposed architecture has the highest efficiency compared to the other two architectures. The PQ_SCB bandwidth utilization is keep below 95\%, although the numbers of HD channels are 40. The reason why our proposed architecture has better utilization is that the IPTV server only need sending the streams once per channel, even if more than thousands users 
request for that channel. In the share_unicast, the IPTV server need to send one streams to each user request, thus increasing the bandwidth consumption and the queue length. However, both share_multicast and share_SCB have zero queue length, which mean that with the current bandwidth and buffer can satisfy the entire user request. The other reason is that the share_multicast will not send one streams to each user request, instead sending the streams to the group of users with the same channels. Another important aspect is that because of abovementioned method of how to send the streams to the users, we can reduce the power consumption of the OLT up to $90 \%$ and $20 \%$ compared with PQ_unicast and PQ_multicast, respectively.

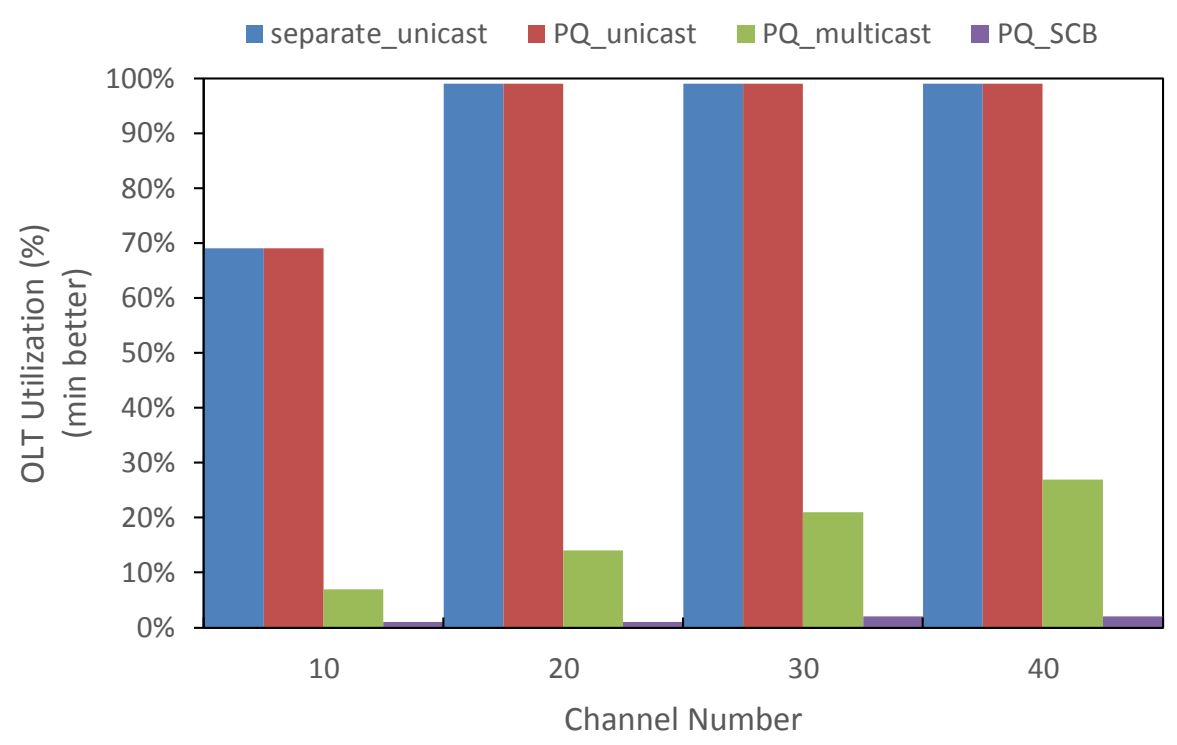

Figure 9. OLT Utilization

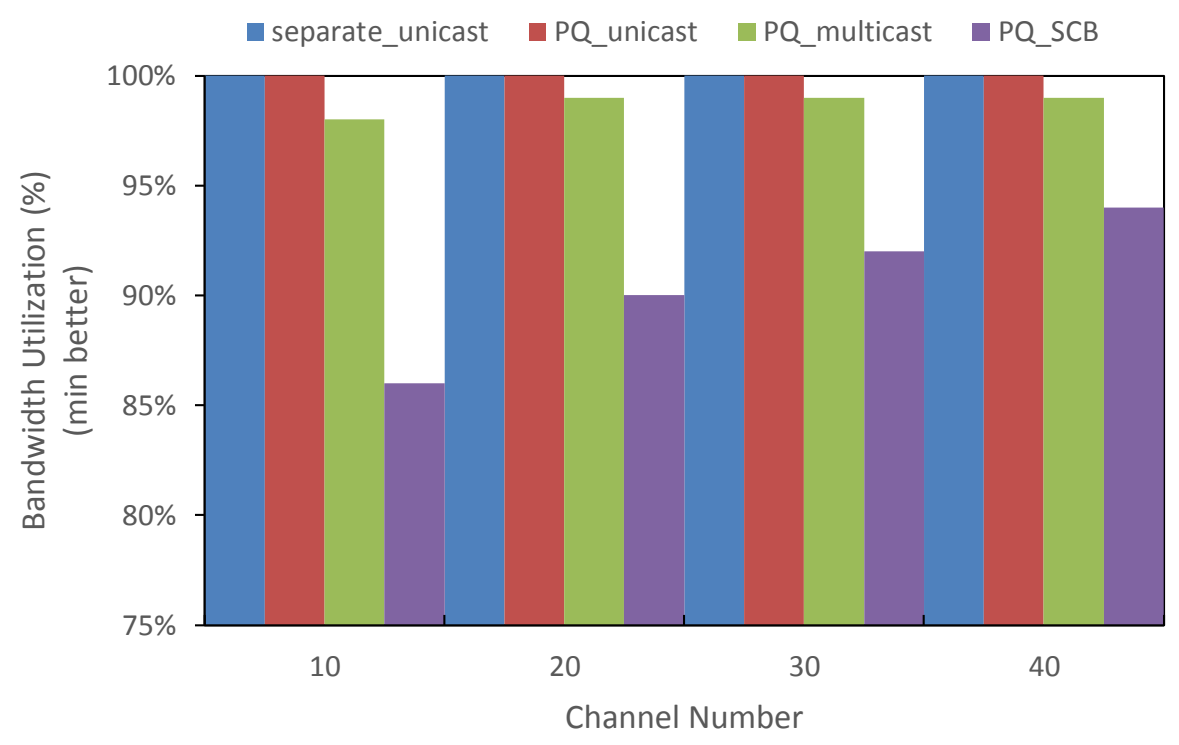

Figure 10. Bandwidth Utilization 
Table VII. Simulation Results of PQ_unicast - PQ_multicast and PQ_SCB Queues System with Different Scenarios

\begin{tabular}{|c|c|c|c|c|c|c|c|c|c|}
\hline $\begin{array}{c}\text { PQ_ } \\
\text { Unicast } \\
\text { No. of } \\
\text { Channel }\end{array}$ & $\begin{array}{c}\text { EF } \\
\text { Buffer } \\
\text { Packet } \\
\text { Loss }\end{array}$ & $\begin{array}{c}\text { EF } \\
\text { Bandwidth } \\
\text { Packet } \\
\text { Loss }\end{array}$ & $\begin{array}{c}\text { AF Buffer } \\
\text { Packet } \\
\text { Loss }\end{array}$ & $\begin{array}{c}\text { AF } \\
\text { Bandwidth } \\
\text { Packet } \\
\text { Loss }\end{array}$ & $\begin{array}{c}\text { BE } \\
\text { Buffer } \\
\text { Packet } \\
\text { Loss }\end{array}$ & $\begin{array}{c}\text { BE } \\
\text { Bandwidth } \\
\text { Packet } \\
\text { Loss }\end{array}$ & $\begin{array}{c}\text { Number } \\
\text { Out } \\
\text { (min } \\
\text { better) }\end{array}$ & $\begin{array}{l}\text { OLT } \\
\text { Util. } \\
\text { (min } \\
\text { better) }\end{array}$ & $\begin{array}{c}\text { Bandwidth } \\
\text { Util. } \\
\text { (min } \\
\text { better) }\end{array}$ \\
\hline 10 & 0 & $1.8 \mathrm{E}+06$ & 0 & $5.5 \mathrm{E}+07$ & 0 & $1.6 \mathrm{E}+05$ & $5.7 \mathrm{E}+07$ & $69 \%$ & $100 \%$ \\
\hline 20 & 9,319 & $1.8 \mathrm{E}+06$ & 14265917 & $9.6 \mathrm{E}+07$ & 817 & $1.6 \mathrm{E}+05$ & $1.1 \mathrm{E}+08$ & $99 \%$ & $100 \%$ \\
\hline 30 & 17,588 & $1.8 \mathrm{E}+06$ & 43587003 & $1.2 \mathrm{E}+08$ & 1,630 & $1.6 \mathrm{E}+05$ & $1.7 \mathrm{E}+08$ & $99 \%$ & $100 \%$ \\
\hline 40 & 27,922 & $1.8 \mathrm{E}+06$ & 76247580 & $1.5 \mathrm{E}+08$ & 2,551 & $1.6 \mathrm{E}+05$ & $2.2 \mathrm{E}+08$ & $99 \%$ & $100 \%$ \\
\hline $\begin{array}{c}\text { PQ_ } \\
\text { Multicast } \\
\text { No. of } \\
\text { Channel }\end{array}$ & $\begin{array}{c}\text { EF } \\
\text { Buffer } \\
\text { Packet } \\
\text { Loss }\end{array}$ & $\begin{array}{c}\text { EF } \\
\text { Bandwidth } \\
\text { Packet } \\
\text { Loss }\end{array}$ & $\begin{array}{c}\text { AF Buffer } \\
\text { Packet } \\
\text { Loss }\end{array}$ & $\begin{array}{c}\text { AF } \\
\text { Bandwidth } \\
\text { Packet } \\
\text { Loss }\end{array}$ & $\begin{array}{c}\text { BE } \\
\text { Buffer } \\
\text { Packet } \\
\text { Loss }\end{array}$ & $\begin{array}{c}\text { BE } \\
\text { Bandwidth } \\
\text { Packet } \\
\text { Loss }\end{array}$ & $\begin{array}{c}\text { Number } \\
\text { Out } \\
\text { (min } \\
\text { better) }\end{array}$ & $\begin{array}{l}\text { OLT } \\
\text { Util. } \\
\text { (min } \\
\text { better) }\end{array}$ & $\begin{array}{c}\text { Bandwidth } \\
\text { Util. } \\
\text { (min } \\
\text { better) }\end{array}$ \\
\hline 10 & 0 & $1.7 \mathrm{E}+06$ & 0 & $5.2 \mathrm{E}+06$ & 0 & $1.5 \mathrm{E}+05$ & 7.1E+06 & $7 \%$ & $98 \%$ \\
\hline 20 & 0 & $1.8 \mathrm{E}+06$ & 0 & $1.1 \mathrm{E}+07$ & 0 & $1.6 \mathrm{E}+05$ & $1.3 \mathrm{E}+07$ & $14 \%$ & $99 \%$ \\
\hline 30 & 0 & $1.8 \mathrm{E}+06$ & 0 & $1.6 \mathrm{E}+07$ & 0 & $1.6 \mathrm{E}+05$ & $1.8 \mathrm{E}+07$ & $21 \%$ & $99 \%$ \\
\hline 40 & 0 & $1.8 \mathrm{E}+06$ & 0 & $2.1 \mathrm{E}+07$ & 0 & $1.6 \mathrm{E}+05$ & $2.3 \mathrm{E}+07$ & $27 \%$ & $99 \%$ \\
\hline $\begin{array}{c}\text { PQ_ } \\
\text { SCB } \\
\text { No. of } \\
\text { Channel }\end{array}$ & $\begin{array}{c}\text { EF } \\
\text { Buffer } \\
\text { Packet } \\
\text { Loss }\end{array}$ & $\begin{array}{c}\text { EF } \\
\text { Bandwidth } \\
\text { Packet } \\
\text { Loss }\end{array}$ & $\begin{array}{c}\text { AF Buffer } \\
\text { Packet } \\
\text { Loss }\end{array}$ & $\begin{array}{c}\text { AF } \\
\text { Bandwidth } \\
\text { Packet } \\
\text { Loss }\end{array}$ & $\begin{array}{c}\text { BE } \\
\text { Buffer } \\
\text { Packet } \\
\text { Loss }\end{array}$ & $\begin{array}{c}\text { BE } \\
\text { Bandwidth } \\
\text { Packet } \\
\text { Loss }\end{array}$ & $\begin{array}{c}\text { Number } \\
\text { Out } \\
\text { (min } \\
\text { better) }\end{array}$ & $\begin{array}{l}\text { OLT } \\
\text { Util. } \\
\text { (min } \\
\text { better) }\end{array}$ & $\begin{array}{c}\text { Bandwidth } \\
\text { Util. } \\
\text { (min } \\
\text { better) }\end{array}$ \\
\hline 10 & 0 & $1.3 \mathrm{E}+06$ & 0 & $2.0 \mathrm{E}+05$ & 0 & $1.1 \mathrm{E}+05$ & $1.6 \mathrm{E}+06$ & $1 \%$ & $86 \%$ \\
\hline 20 & 0 & $1.4 \mathrm{E}+06$ & 0 & $4.6 \mathrm{E}+05$ & 0 & $1.3 \mathrm{E}+05$ & $2.0 \mathrm{E}+06$ & $1 \%$ & $90 \%$ \\
\hline 30 & 0 & $1.5 \mathrm{E}+06$ & 0 & $7.3 \mathrm{E}+05$ & 0 & $1.4 \mathrm{E}+05$ & $2.4 \mathrm{E}+06$ & $2 \%$ & $92 \%$ \\
\hline 40 & 0 & $1.6 \mathrm{E}+06$ & 0 & $1.0 \mathrm{E}+06$ & 0 & $1.4 \mathrm{E}+05$ & $2.7 \mathrm{E}+06$ & $2 \%$ & $94 \%$ \\
\hline
\end{tabular}

As can be seen in Table VII, our proposed queuing system improve the separate_unicast queuing system, regardless of EF and BE packet loss buffer. This happen because we dividing the queue into three dedicated queue traffic classes, therefore, we can prevent the AF traffic class monopolizing the buffer occupancy as happened in share queuing system. Yet, we can still keep the AF packet loss buffer lower than in share queuing system. As for the other parameters simulation results are summarized in Table VII.

\section{CONCLUSION}

In this paper, we propose a new technique that can accommodate large number of IPTV clients without adding extra bandwidth and resources both at the OLT. We used the so called "single copy broadcast" (SCB) over EPON system for efficiently distribute live IPTV traffics to the users. The server only needs to send one stream to the groups of useras without any limitation on the number of group. Moreover, we also proposed two different queuing system models to tackle the buffer overflow in the current queuing system model (i.e., FIFO). These two queuing models can improve the QoS of highest priority traffic (i.e., voice/EF), since no packet buffer loss was found compared with current system. Simulation results have shown that our proposed mechanism can improve the QoS metrics and system performance in terms of bandwidth consumption and power consumption. 


\section{REFERENCES}

[1] Erramilli, P. Pruthi, and W. Willinger. 1997. Fast and physically-based generation of selfsimilar network traffic with applications to ATM performance evaluation," in 29th conference on Winter simulation, Atlanta, Georgia, United States, pp. 997-1004.

[2] C.M. Assi, Y. Ye, S. Dixit, and M.A. Ali. 2003. Dynamic bandwidth allocation for quality-of-service over Ethernet PONs. IEEE Journal on Selected Areas in Communications, vol. 21, issue 9, pp. 1467-1477, Nov 2003.

[3] A. Shami, X. Bai, N. Ghani, C.M. Assi, and H.T. Mouftah. 2005. QoS control schemes for two-stage ethernet passive optical access networks. IEEE Journal on Selected Areas in Communications, vol. 23, issue 8, pp. 1467- 1478, Aug 2005.

[4] J. Choi, A.S. Reaz, B. Mukherjee. 2012. A Survey of User Behavior in VoD Service and Bandwidth-Saving Multicast Streaming Schemes. IEEE Communications Surveys \& Tutorials, vol.14, no.1, pp.156-169. available at: http://www.ieee802.org/3/efm/public/jul01/presentations /sala_1_0701 .pdf

[5] C.C Sue, and H.W Cheng, 2010. A fitting report position scheme for the gated IPACT dynamic bandwidth algorithm in EPONs. IEEE/ACM Transactions on Networking, vol. 18, issue 2, pp.624-637, April 2010.

[6] C.A. Chan, M. Attygalle, and A. Nirmalathas. 2010. Remote repeater-based EPON with MAC forwarding for long-reach and high-split-ratio passive optical networks. IEEE/OSA Journal of Optical Communications and Networking, vol. 2, issue 1, pp. 28-37, January 2010.

[7] H.T. Lin, C.L. Lai, W.R. Chang, and S.J. Hong. 2010. Design and analysis of a WDM EPON for supporting private networking and differentiated services. IEEE/OSA Journal of Optical Communications and Networking, vol. 2, issue 5, pp. 266-282, May 2010. 